\title{
TAPPING TALENTS IN INDIA THROUGH DIASPORAS NETWORK: OPPORTUNITIES AND CHALLENGES ${ }^{1}$
}

\author{
Falendra Kumar Sudan, PhD*
}

\begin{abstract}
India had a strong cultural emphasis on education both at private and government level. Since 1990s, government spending on education has been growing at $12 \%$ a year, of which roughly a fifth goes towards higher education. By 2030, share of skilled labour in working population will be just $6.2 \%$ compared to $14 \%$ for world as a whole and $40 \%$ in high income countries. While India has made rapid strides in expanding higher education systems, she still faces a number of challenges in terms of effectively utilizing existing supply of talent as well as increasing it sufficiently to meet demands of rapidly growing economy. How to leverage expertise and knowledge of Diasporas for benefit of India is main issue the paper addresses and emphasizes beginning of a new agenda of promoting policy reform and institutional innovation in collaboration with Diasporas networks, which can be crucial bridges between policy, technological and managerial expertise and local scenarios. The public policy reform, educational innovations and promotion of a knowledge-based private sector are few areas where Diasporas members could team up with local governments and external funding agencies to tap Indian talents and promote equitable development.
\end{abstract}

Key words: Diaspora network, Talent, Skill mobility, Asia, Europe, India

\section{INTRODUCTION}

The 'intangibles' such as technology, ideas, creativity, and innovation have important role in economic growth. Behind these intangibles, there is 'human talent', an inner capacity of individuals to develop ideas and objects (UNDP, 2003). The spread of education and build-up of talent and professional skills and knowledge are necessary but not sufficient to develop talent, given organizational and institutional constraints. Human capital flow entails an international transfer of resources in the form of human capabilities and skills. Added to this, globalization, trade liberalisation, growing emphasis on knowledge economy, development of advanced ICT services, etc. has encouraged mobility of highly skilled from developing to developed countries, often termed as 'brain drain'. From developmental perspective, the outward flow of highly

\footnotetext{
1 Paper presented in the International Conference on "Tapping the transnational brains: skilled nobilities and development", held on 16 and 17 December 2010 at International Development Studies Faculty of Geosciences, Utrecht University, PO Box 801153508 TC Utrecht, Netherlands. The suggestions offered by the participants especially Prof. Binod Khadria and Dr. Gery Nijenhuis are deeply acknowledged.
}

\footnotetext{
* Mr. Sudan is Associate Professor, Department of Economics, University of Jammu, Jammu, Jammu and Kashmir, India-180 006. E-mail:fk_sud@rediffmail.com
} 
skilled labour to developed world causes negative consequences on growth and income levels in sending countries. In addition to unaffordable loss of considerable investment undertaken in generating skills, already poor source countries lose their potentially most enterprising and ambitious young population, limiting future leadership and stifling the development of a more dynamic private sector (Ndulu, 2004). Recently, the 'brain gain' hypothesis is getting momentum. It emphasized the significance of knowledge and skills contribution of Diaspora for socio-economic development of their home country through direct return or network building process of the emigrated knowledge elite (Hunger, 2002). The positive aspects could take such forms as incentives to acquire higher education, remittances, return migration of skilled professionals and the creation of business networks.

The financial and social capital dimensions of this process also take place with changes in human capital stock and flows. The relative success of Taiwan, Republic of Korea and Ireland in fostering return migration has been attributed to opening of their economies and policies to foster domestic investments in innovation and Research and Development (R\&D). Developing Asian countries with some infrastructure in $R \& D$, like India, are more likely to attract the return of migrants, as well as money and business contacts. A "scientific Diaspora" and "immigrant entrepreneur networks" can also help sending countries capture benefits and know-how from overseas emigrants. Indian highly skilled professionals in the United States (US) have been the primary drivers of knowledge and capital flows to India. The Indian government has contributed to the emergence of these private networks through legislative and tax rules that encourage remittances and investment from Indians abroad. With above backdrop, the main issue the paper addresses is how to leverage expertise and knowledge of Diasporas for benefit of India.

\section{HIGHLY-SKILLED AND THE ASIAN AND EUROPEAN TRAJECTORIES}

\section{i. European Talent and Mobility}

The innovation is research-based activity and requires the presence of highly-qualified scientists and researchers. In the race for innovation and economic leadership, preventing an exodus of talented researchers is crucial in European countries. EU produces more science graduates per capita (Ph. Ds) than US but has fewer researchers (5.36 per 1,000 workers against 8.66 in the US and 9.72 in Japan). Over the course of the 1990s, the European research area was a collection of national systems with very little coordination. Gradually that has changed as the European Commission have exerted more influence, as central funding for research has increased and as it becomes clear that to compete on the world stage with players like the US, a more cohesive European strategy is needed (European Commission, 2003). This change in mind set became most apparent at the Lisbon Summit of Heads of State in 2000 which set the goal for Europe "...to become the most competitive and dynamic knowledge-based economy region 
in the world" and the follow-up summit in Barcelona in 2002 that set a quantitative target of increasing the EU's R\&D intensity (total R\&D / GDP) from about $1.9 \%$ to a level approaching $3.0 \%$ by 2010 (European Commission, 2002).

Since at least half of R\&D spending goes to pay the wages of researchers, increasing $R \& D$ by this amount will require a significant increase in the number of researchers. Estimates of the number of additional researchers needed to meet R\&D spending targets depend on the assumptions made, but if it is assumed that R\&D spending per researcher in EU begins to look more like that of the US and that annual rate of growth in GDP is same as it has been for past decade (2\%), then EU would need approximately 500000 more researchers by 2010 to meet its 3\% target, an increase of more than $50 \%$ over 2000 levels (Guellec, 2002; Sheehan and Wyckoff, 2003). EC itself estimates a need for an additional 700000 researchers to reach the goal (European Commission, 2003). However, it seems almost certain that Europe will not achieve such targets, and so far the exodus of European researchers has also shown no sign of weakening. In 2000, the EU15 exhibited a net loss of 0.120 million post-secondary educated workers in its exchanges with the rest of the world (Docquier, Lowell and Marfouk, 2009). This does not account for EU emigrants to non-OECD countries and net deficit represented only $0.3 \%$ of European skilled labour force compared with huge gains (12.5\% of skilled labour force) in US, Australia, Canada and New Zealand. European deficit of post-secondary educated workers in exchanges with traditional immigration countries was particularly important (2.6 million individuals in 2000). It was more or less compensated numerically by the large entry of skilled workers from developing countries. The quantitative loss of EU15 is rather low, qualitatively, however, it is likely to be more important as graduates from developing countries are usually less productive than domestic graduates and employment rate gap between natives and immigrants tends to increase with level of schooling (Dumont and Lemaitre, 2007). Besides, European 'brain drain' concerns top-skill workers.

Adding another 500000 to 600000 researchers to the EU workforce by 2010 will present a challenge to Europe and a potential bottleneck for satisfying goal of 3\% R\&D intensity (Sheehan and Wyckoff, 2003). Few analysts believed this goal could be reached when it was set in 2000 and 2002, and even fewer think it was possible in 2005 since R\&D intensity of EU was hovering at $1.9 \%$. But it is a mistake to interpret this goal simply on an analytical basis - it is a political goal and in this sense it has already begun to succeed. Innovation policy is now high up on policy agenda of Europe (Brown, 2005). A key element of this concern focuses on highly-skilled. Europe faces a dual problem, as do most OECD countries: while they try to attract more researchers to bolster their R\&D activity they are faced with a rapidly aging population and an increasing rate of retirement of many researchers. This combination creates a need to produce more researchers from the native population, especially from relatively untapped reservoirs like women, while at the same time becoming more aggressive about attracting highly- 
skilled from abroad and stemming outward migration of Europe's brains (Saint-Paul, 2004).

It is estimated brain drain of European researchers employed in S\&T or European $\mathrm{Ph}$. D holders. Brain drain of graduates employed in S\&T is strongly correlated with general brain drain to US and to OECD with coefficients of correlation of 64 and $70 \%$, respectively(Docquier, Lowell and Marfouk,2009). However, brain drain in R\&D is on average 5.3 times larger than general brain drain to US. In other words, European skilled emigration to US is biased toward S\&T activities. The biggest biases are observed in Belgium, France, the Netherlands and UK. Brain drain of European Ph. D holders is less correlated with general brain drain to US with coefficients of correlation of 33 and $51 \%$, respectively but is still on average 2.2 times higher than for all postsecondary educated workers. Thus, Europe is suffering from a large emigration of scientists and top-skill workers. Europeans emigrants are increasingly drained from top of distribution of skills and ladder of occupations (engineers, researchers and university instructors) that matter most for knowledge economy (Tritah, 2008). Is there any positive feedback effect associated with European brain drain? Clearly, given the level of development in Europe, one should not expect strong incentive effects and huge amount of remittances. Return migration is more likely to play a role. Nevertheless, returns rate in all large European countries have decreased except for UK. Does emigration of European scientists' threaten R\&D performances, or do low R\&D investments stimulate brain drain? European investments in "knowledge" (sum of R\&D expenditures, investments in software, higher-education spending) represents $3.8 \%$ of GDP, against $5 \%$ in Japan and $6.6 \%$ in US. The target of increasing European R\&D spending from $1.8 \%$ in late 1990s to 3\% of GDP in 2010 set by Lisbon Council 2000 has hardly increased and remains below $2 \%$ in a majority of countries and only Sweden (already at more than 3\% in 1995) and Finland meet the objective.

Looking at correlations between R\&D spending and growth, it has been shown that "countries that have increased their R\&D spending more in proportion to their GDP are also those whose expatriation of scientists and engineers to the US has increased the least" (Tritah 2008). Tritah finds the brain-drain to be a symptom of lack of demand for skilled labour in Europe which has followed rise in skilled labour supply in 1990s and strongly supports idea that expatriation of scientists and engineers is due to lack of resources dedicated to research in their countries. Low investments in knowledge also translate into low wages for scientists, unstable or unattractive jobs, competition with non-Ph. D graduates, excess load of administrative tasks, etc., which are major push factors among European researchers. Most European governments have eased restrictions on entry for skilled workers, and many are going much further, not just letting them in but rather engaging in what has been termed an international competition to attract talent. Germany has made it easier for skilled workers to get visas. Britain has offered more work permits for skilled migrants. France has introduced a "scientist visa". Many countries are making it easier for foreign students to stay on 
after graduating. Ireland's government works hard to recruit overseas talent. Many countries regard universities as ideal talent-catching machines, not only because they select students on the basis of ability but also because those students bring all sorts of other benefits, from spending money to providing cheap research labour. France is aiming to push up its proportion of foreign students from about $7 \%$ now to $20 \%$ over time. The global war for talent is likely to intensify. Most developed countries are already struggling to find enough doctors and teachers, and are wondering how they will manage when the baby boomer generation retires (The Economist, 2006).

Many practical policy recommendations have been proposed by the European Commission to curb or invert EU scientists' brain drain. A recent proposal, officially endorsed by EU in 2008, is to create by 2010 a European Blue Card meant to attract highly-qualified workers. Blue card would grant such workers and their families with rights to work and live in EU countries for 3 to 5 years. More precisely, Blue Card would allow an immigrant to work in one EU country. After first 18 months, worker could then move to another country, but would still have to apply for a new Blue Card within a month of arrival (Von Weizsacker, 2006, 2008). Blue Card can help attenuate labour shortages for certain professions. However, it is unlikely that it can help Europe compensate its deficit in science and technology. Blue Card proposal appears too uncertain (with uncertainty regarding mainly chances of renewal and transferability across EU countries) and not generous enough to significantly change attractiveness of European labour market for scientists and talented workers.

\section{ii. Asian Skill Mobility to EU}

After US, Japan has second largest national S\&T system in the world as measured by absolute R\&D expenditures and number of researchers. This effort has been sustained from an indigenous supply of highly-skilled scientists, engineers and technicians. But as Japan's population ages and as shortages in select areas like software engineers arise, Japan is beginning to enact policies aimed at attracting highly-skilled from abroad, particularly from India and China (METI, 2003; OECD, 2004a) and has more than doubled the number of postdocs provided to foreign, mainly Asian, scientists (Mahroum, 2002). While the flows of highly-skilled people to Japan are still relatively modest, they are beginning to grow, reflecting another change in global market for highly-skilled. In 1992, number of foreigners with "special and/or technical skills" registered in Japan for purposes of employment was about 85,000, this climbed modestly to about 98,000 in 1996 after which point the level grew more rapidly, reaching about 118,000 in 1998 and 169,000 in 2001 - nearly double the 1992 level (METI, 2003). Some of fastest growing occupations include professor, researcher and engineer. Over half of all foreign engineers in Japan come from China - a near doubling of absolute number between 1994 and 2001. Korea is second, accounting for about 10 percent. India accounts for only about $7 \%$ of foreign engineers in Japan in 2001, but this represents a $53 \%$ increase from 2000 . 
China and India are international flows of brains (Schaaper, 2004). Huge demographic size of these countries means that tails of skills distribution are huge. Until very recently, they had no where to go but abroad to pursue an education and career. In fact government policy in both countries had an explicit goal of promoting the diaspora (OECD, 2001) and US was overwhelming destination of these people. While flows of highly-skilled Chinese to US are still considerable, there are several signs that various factors that "pushed" highly-skilled Chinese away from China are changing as Chinese S\&T system grows and opportunities to study, conduct research and work in a high-tech company expand. These developments suggest that increasingly China will become a competitor for highly-skilled, especially for its indigenous supply. Two changes in the flow of Chinese students are appearing. First is that the US's dominance as a host country to Chinese students is decreasing as EU attracted increasing numbers of Chinese students, almost doubling its share during 1998-2002. Second change is that since 1999, China has greatly expanded enrolment of students in its own universities (Song and Xuan, 2004). This rapid growth is likely to continue since number of doctoral students admitted has rapidly increased, jumping from about 14,500 in 1998 to 48,700 in 2003. Majority of doctoral degrees earned between 1992 and 2003 in China were for engineering (38\% of total), natural sciences $(22 \%)$ and medicine (15\%). In comparison, small number of Chinese students earned S\&E doctorates in US in recent past, a change in trend attributed to possibility of increased capacity for graduate education in China (Johnson, 2001).

In most Asian economies, number of researchers has been growing steadily over last decade. While differences in terms of quality may exist, China now counts more researchers than Japan and is quickly approaching EU level (OECD, 2004b). Since about half of all R\&D expenditures goes to pay wages of researchers, level of Chinese $R \& D$ has grown significantly as well. China's R\&D effort has been catching up rapidly, especially since 1999 . China spent USD 16 billion on R\&D in 2001, which put it not only behind US, EU and Japan, but also significantly behind Germany, France and UK. In an effort to stimulate business innovation, China continues to privatize its R\&D institutes, converting over 1,000 centres in 2002. Associated with this has been construction of over 60 industrial parks, with intent of luring home overseas highlyskilled Chinese. These developments and government policy of encouraging highly skilled overseas Chinese to return to China has led to a return-flow of highly-skilled Chinese that has grown on average by $13 \%$ a year in the 1990s albeit significantly below the rate of increase in the outflow (OECD, 2004a). One indicator of this growing Chinese demand for S\&T personnel is bidding up of wages that is occurring (Marsh, 2004). Thus, while a huge wage differential exists between China and EU countries for ordinary manufacturing workers, gap for engineers and scientists is narrowing quickly.

There has been strong links among European countries and East Asian economies not only through flow of trade and services but also in terms of talent mobility (Fukasaku, 
2004). Since 1980s, East Asian countries have played a vital role in helping Asia to catch up with the West. Although economic growth was interrupted by 1997-1998 financial crises, it has strongly rebounded recently. East Asian countries like Korea, Malaysia and Thailand have recovered from crises very quickly. Continuation of upturn in economic activities in European countries since 1990s has had major impacts in labour market. Current demographic situation in European countries indicates severe labour shortages over next 25 years (Garson, 2001). Therefore, promotion of immigration would seem to be an effective measure to increase the size of economically active population and ease labour shortage problem. Since mid-1990s, there has been a gradual upturn in migration flows in most EU countries. Recently, many EU countries have adopted policies that promote entry of skilled and highly skilled workers, especially in field of ICT. EU countries have opened their doors to ICT workers as well as other highly skilled professionals. Since mid-1990s, movement of highly skilled workers, especially ICT workers from East Asia to EU countries has been remarkable. Migrants with tertiary education from Malaysia registered highest migration rates to EU countries followed Republic of Korea, Philippines and Chinese Taipei (Carrington and Detragiache, 1998). Migrants with tertiary education from Indonesia and Philippines accounted for more than $70 \%$ of total migrants from each country to EU, while tertiary-educated migrants from China produced only 54\% of all Chinese immigrants to EU (Adams, 2003).

Keeping in view expansion in EU demand for skilled workers in some fields, there is an increasing trend in people graduating in business and related fields as well as mathematics and computer science in East-Asian countries. For example, during 19952000, graduates in business and related fields increased gradually from 85,781 (27\% of total tertiary graduates) in 1995 to 104,537 (29\%) in 2000 in Philippines. Number of graduates in mathematics and computer science also went up from 21,338 (7\% of total tertiary graduates) in 1995 to 34,015 (10\%) in 2002. In addition, most emigrants still have connections and networks in their own countries, so they can feed back knowledge and new technology, which significantly contribute to their countries' economic development (Lucus, 2001). Moreover, highly skilled emigrants have credible backward linkages with their source countries, which can increase availability of knowledge and technology vital to improvement of productivity (Iguchi, 2002). Expatriates and/or members of Diaspora organize networks that stimulate return flows of knowledge, sometimes leading to collaboration with local business entrepreneurs or researchers.

\section{iii. Highly-Skilled and Mobility from India}

India had a strong cultural emphasis on education both at private and government level. Since 1990s, government spending on education has been growing at $12 \%$ a year, of which roughly a fifth goes towards higher education. India's higher education system now ranks alongside that of US in terms of scale. Over 50,000 Indian-born doctors and 15,000 medical students/residents live in US (AAPI, 2009), while there were 6 doctors to every 10,000 inhabitants in India (OECD, 2007). Likewise, 103,260 Indian nationals were enrolled in US universities in 2008-09; while India's tertiary gross enrollment 
ratio was only about $12 \%$, far less than US's $82 \%$ (Institute for Statistics, 2009). Since early 1990s, India has experienced rapid economic growth - averaging over 7\% GDP growth since 1997 and ranked fifth in the world in GDP (purchasing power parity). As a share of GDP total education spending is still lower than in most developed countries. India spends $4.9 \%$ of its GDP on education against $5.7 \%$ in OECD countries. Besides, non-government spending on education is relatively high proportion of total at $25 \%$. Over 12 million students were enrolled in universities and colleges of India in 2009 . Roughly $20 \%$ of students study commerce, economics or management related courses and tertiary enrolment rates are less than half those in advanced economies such as United Kingdom (UK). Thus, while graduate populations are large in terms of absolute numbers, for foreseeable future India's economies will remain dominated by low skilled labour. It is estimated that by about 2025 India will have $25 \%$ of world's total workforce (India Labour Report, 2009). By 2030, share of skilled labour in working population will be just $6.2 \%$ compared to $14 \%$ for world as a whole and $40 \%$ in high income countries.

All this creates a big challenge as India aspires to move up the value chain. Majority of job creation over next twenty years needs to be in low skill activities as India's supply of high skill professions is actually quite low. Entrepreneurs operating in India increasingly report shortages of key talents as a major barrier to their future growth. A lack of managerial talent is biggest barrier to Indian based companies' ability to expand in to global markets. While India has made rapid strides in expanding higher education systems, she still faces a number of challenges in terms of effectively utilizing existing supply of talent as well as increasing it sufficiently to meet demands of rapidly growing economy. In 2008, India had the highest level of H-1B and L-1 admissions for high-skill employment (Monger and Barr, 2009). India represents major Asian source of supply of internationally mobile highly-skilled. Supply of talent from India, especially for IT and health professionals, is in demand from a growing number of countries, including India itself. IT sector in India, in particular, had shown significant growth with a compounded annual growth rate of 55\% from 1992 to 2000. In 2008-2009, revenue of IT and business process outsourcing (BPO) industry in India was estimated at US $\$ 71.7$ billion with an annual growth rate of $12 \%$ (MCIT, 2009), directly employing 2.23 million individuals and indirectly employing another 8 million individuals. Moreover, their export market was estimated at US $\$ 40.4$ billion with US accounting for $60 \%$ of exports.

Coupled with this is growing capacity of Indian institutions of higher-learning to educate Indians at home, development of high-tech industries fuelled by foreign direct investment and expansion of research opportunities in India that collectively reduce "push" that used to send highly-skilled abroad in search of rewarding careers. In fact, there is increasing evidence that Indians who went abroad are returning home. As second large source country for highly-skilled, these changes within India will have repercussions for EU market for the highly-skilled. India is increasing enrolment of 
students in Indian higher-education institutions, albeit at a slower rate. Over 1990s, India increased its student enrolment by $47 \%$, climbing from 5.2 million to 7.7 million students. Rate of growth in professional tracks like engineering \& technology and medical sciences was higher than average at $51 \%$. At doctorate-level, role of natural sciences is more prominent, accounting for over a third of doctorate degrees in 199899. Thus, while over 800 Indians earned science \& engineering doctorate degrees in US in 2001, Indian system itself produced more than five-times that number (Khadria, 2004a).

In past, many of these highly-skilled graduates from Indian institutions would migrate abroad in search of work in S\&T careers (OECD, 2001). While this continues, a significant number remain in India, causing stock of S\&T personnel to increase by $60 \%$ over 1990s and reached nearly 8 million. India has approximately same absolute number of researchers as Canada or Korea (95000) albeit with a much lower per-capita density (OECD, 2003). A key factor behind advancement of Indian S\&T system has been IT sector, particularly software and computer services sectors. Employment of IT professionals in India has increased almost tenfold over past 10 years (Khadria, 2004a) and this trend is likely to continue through "off shore" work too. Growth of Indian IT sector is also attributable to IT down-turn in US which forced many Indians on temporary visas to return home. These people leave US with skills and know-how obtained from working in places like Silicon Valley as well as contacts to venture capitalists, US firms and broader IT community, especially other fellow Indians who remain in US. While this return flow to India is still relatively modest, as opportunities grow in India, it is increasing to the point where India's NASSCOM (National Association of Software \& Service Companies) estimates that the return flow of IT professionals now offsets the outflow. These return flows of high-skilled is another indication of how S\&T system in India is maturing. A case study of 45 returnees to India, undertaken for the OECD, suggests that a range of "pull" factors were main motivating forces, but several "push" factors - 'the fear of ethnic/racial problems in host country' and a 'negative attitude of employer towards immigrant employees' - were also key (Khadria, 2004b). Due to its large pool of talent and relative low cost, India has ramped up its R\&D as multinational enterprises have set up labs (Rai, 2004).

According to Global Talent Pyramid Model (GTPM), ability of a country to attract talents internationally is determined by three main factors: attractiveness of national ecosystem vis-à-vis local and foreign talent, existence of a critical mass in "national talent pool" (stock and flow), and overall efficiency/quality of economy and society (Ivaturi, 2009). Each particular country will benefit from specific advantages and encounter unique challenges in building its own talent pyramid (UNDP, 2007; UNESCO, 2007). For example, in European countries, issue of e-skills (i.e., skills for knowledge society) has started to attract priority attention of a number of companies (Lanvin and Passman, 2008). A growing number of governments in Europe and Asia 
are increasingly worried about their inability to produce number of programmers, analysts and software architects that its industries will need in coming years. However, this inability may be tip of a much larger iceberg. Lack of engineers has recently become a major concern in countries such as Germany and Japan. These countries are looking at India to obtain talents they need. However, keeping in view expected rates of growth of Indian economy, Indian scientists and engineers are less likely to leave their own countries. Hence, talent pool available in India is likely to increase, while its international mobility will decrease.

Local companies are less equipped with ability to produce enough scientists and engineers in China, Spain, Italy, or smaller European economies. Therefore, these companies are likely to continue paying a premium to attract necessary talent, and to pressure their respective governments to improve dimensions at bottom of the GTP (environment) as well as at top (by attracting more presence by foreign companies, or by enhancing outsourcing capabilities through better IT infrastructure). In Western Europe, there is need to improve attractiveness of careers such as scientists and engineers especially among female students. Ability to produce talents required in European countries will stem directly from degree of investment made in their respective educational systems, specifically tertiary enrollment. Asian countries such as Singapore will continue to benefit from a comparative advantage in tertiary education followed by India and China, while relatively low scores by European countries of Italy, Spain, or Portugal should be of particular concern (World Economic Forum, 2008). In coming years the availability of talented knowledge workers will not grow as quickly as global demand for their skills. Therefore, talent mobility will narrow existing gap between supply and demand. Sharp differentials are noticed in key GTPM variables in India and Singapore. Singapore has a strong advantage over India in business environment. For example, it takes 10 times longer to enforce a contract in India than in Singapore. Likewise, time required to start a business is less than a week in Singapore compared to a month or so in India. However, India performed better in number of scientists and engineers available and education expenditure than Singapore (World Bank Group, 2008; World Economic Forum, 2009; UNESCO, 2009; World Bank, 2008; UNDP, 2008).

In long-term, the demographics of these two nations present different implications for above variables. There is almost symmetrical situations between two countries in 2008 and 2025, with a marked aging of Singapore's population, while India's population is only starting to "narrow at the base" and will still display an age pyramid with a majority of population below 45 years of age (US Census Bureau, International Database, 2009). By pooling talent data and demographic information, one can identify some striking challenges and questions regarding talent availability in two countries. By 2025, India's population will be largely concentrated in 20-50 age group. Given its current high level of education expenditure, India will have a very large talent pool in 2025. Will India be in a position to leverage growth and competitiveness 
potential of such a large talent pool? Assuming that country maintains its current rate of growth, improvements in business environment may become a crucial condition to achieve this goal. India still enjoys a surplus of talented workers in some areas, such as IT. However, it remains to be seen whether such a surplus will continue to benefit Australia, Canada, US and Western Europe in 2025, as is the case today. If needs of India's economy continue to grow at today's pace, and if other Asian economies (such as Singapore) continue to exhibit a structural deficit in area of talent, one can envisage that Indian talented workers will move progressively closer to home, and possibly stay home.

Current values of some key GTPM variables (such as university-industry research collaboration, time needed to start a business, and quality of scientific research institutions, for example) seem to indicate that, in near future, India's talent pool will be more effectively utilized in neighboring Asian countries (and possibly in Middle East) than in India itself. This should lead to emergence of a regional India-based nebula (in IT services) rather than to a set of large Indian companies with headquarters in India, wherein, advantage will be made of combining areas of national excellence. For example, it is likely that in exchange for direct access to large and fast-growing Indian market, Singapore could provide capital and infrastructure from its companies and universities for development of high-end research activities. In return, talented Indian citizens could provide complex IT services at a competitive cost. Similar crossborder ventures could be developed within Asia and with other regions of world. In some sectors (e.g. aerospace and nuclear industries), India could provide talent to international private ventures, based on volume and high-end R\&D. All these point to significant shifts in ways in which talented workers will flow within Asia in coming years.

Some other studies confirm that similar changes will also affect other countries (Heidrick and Struggles/Economist Intelligence Unit, 2007). In 2012, US will maintain its position as world's leading country for nurturing and developing talented workers, however, it will face increasing competition from UK, which will rise to second place. Asia-Pacific countries will offer tough competition to US and Europe in attracting and nurturing talented workers. China and India rank among top 10 talent hotspots worldwide. Russia is expected to fall from 6th to 11th place by 2012, with Brazil slipping from 18th to 19th. Asia is well positioned to move ahead in talent rankings. Besides India, other countries are expected to continue to feature at top of such rankings, or to improve by 2012, such as Malaysia (remaining in $12^{\text {th }}$ place), Korea, Rep. (improving from 15th to 13th), or Japan (from 16th to 14th). China is set to exploit its natural demographic advantage by significantly improving its compulsory education system and developing a much better environment for producing and nurturing talent, which will enable the country to build on its manufacturing base and attract increasing numbers of foreign-owned businesses. Despite strong performance of US overall, its labour market is still likely to become less open and flexible by 2012 amidst fears of 
terrorism. Therefore, US would rank $9^{\text {th }}$ worldwide on Global Talent Index (GTI), only one rank ahead of China. Thus, different countries have different talent endowments linked to their demography, educational system and ability/will to attract, retain, or export talented workers. Many European countries will face serious "talent crunches" in coming years in e-skills, scientific and engineering professions. India will be increasingly faced with a talent shortage at home due to fast economic growth and need to develop appropriate national talent pools.

\section{iv. Way out through Diaspora Network}

Wealth, prosperity and economic development in a knowledge-based economy depends on people's abilities to out-invent and outwit their competitors, to accommodate to desires and demands of consumer market, and to change jobs or develop new skills. Talent and skills is becoming most precious assets in a knowledgebased economy. It creates a more integrated market for skills and puts a premium on talent. Process of brain drain is intensifying from developing countries of Asia, including India. Some Asian countries including India have been actively working for past two decades to take advantage of new opportunities and lessen risks associated with knowledge-based economy (NCURA, 2006). There has been significant effects of brain drain (Mountford, 1997; Vidal, 1998; Beine et al., 2001), brain gain (Beine et al., 2008) and Diaspora networks channels on source countries (Kerr, 2008; Agrawal et al. 2008; Kugler and Rapoport, 2007; Docquier and Lodigia, 2009). Interaction between expatriate talent and institutions is necessary to use potential and knowledge of Diasporas for development in countries of origin. Quality of these institutions varies widely and Diaspora networks link better-performing segments of home country institutions with forward-looking segments of Diaspora. Latter have potential to generate a virtuous cycle that develops both home country institutions and Diaspora networks. It is vital to understand 'how to trigger and sustain such a virtuous cycle that generates benefits for all parties involved - sending countries, receiving countries, and expatriates themselves' so that programmes and interventions are designed for effective Diaspora networks to transform brain drain into brain gain.

India tends to have a large number of self-identified Diaspora networks focusing on transfer of knowledge. A large part of success of Taiwan's IT sector development in 1980s and 1990s was due to Asian-American engineers who built social and economic bridges linking economies of Silicon Valley and Hsinchu Park. Knowledge leads to increases in total factor productivity and hence economic growth. Thus, knowledge can become main engine of growth if economy satisfies certain preconditions, which include a sufficiently high level of quality human capital stock, a high intensity of domestic innovation and technological adoption, and ICT infrastructure. Besides, overall economic and institutional regime is conducive for knowledge to propagate and become driving force behind productivity and economic growth (Chen and Dahlman, 2004). Most important level of education is tertiary education, which directly influences national productivity, living standards and a country's capacity to compete in global 
economy. Ever increasing brain drain to European countries from Asian countries including India is related to major economic, demographic and political gaps between EU and developing Asian countries. Thus, there is need to understand whether and under what circumstances highly skilled labour mobility causes brain drain, which can be harmful to social and economic development of sending countries or under what condition it directs to circulation of skills, their improvement, and eventual later return. At the same time, high unemployment in sending countries would result in a great under-usage of these skills and therefore eventually to "brain waste".

No doubt, brain drain is a big problem in developing Asian countries, but it can act as a safety valve to relieve pressure of a pressing problem rather than to resolve it. Migration of skilled workers facilitates export of unemployment problem. It alleviates pressure to change structural barriers in improving business climate to return the benefits also to sending country. By attracting talent, host countries could have a positive impact on economic output. In given situation, main question is 'how Diaspora could play a win-win role facilitating development in both directions, toward sending as well as recipient country'? Impact of brain drain depends on skills, former employment, existence and location of a large Diaspora, affected sectors, patterns of trade and production, investment climate, and size and geographical location of country. Sending countries may face both favorable and unfavorable consequences from brain drain. Generally, migrants are highly skilled and educated, younger and more mobile than majority in their country of origin. Sending countries may lose well-educated domestic work force and innovative and motivated youth. Thus, out-migration could lead to a brain drain as well as a youth drain from poorer countries. In some instances, highlyskilled emigration has a negative impact on living standards of those left behind and on growth. Those left behind may suffer because they lose prospect for training and mutually beneficial exchanges of ideas. Provision of key public services with positive externalities, such as education and health may be damaged. Opportunities to achieve economies of scale in skill-intensive activities may be reduced. Society loses its return on high-skilled workers educated at public expense and price of technical services may rise. This means, that if highly educated workers would stay in their countries, they could help to improve governance, improve quality of debate on public issues, encourage education of children and strengthen administrative capacity of state. All these contributions would be impaired in case of brain drain.

However, due to ongoing debate about brain drain impacts on origin countries, it has been emphasized that there are some potential gains from brain drain occurrence too. Return of skilled workers to their home country is a positive occurrence because they may be more efficient than foreigners in transferring knowledge back home because of their understanding of local culture, however, most of highly skilled who are leaving their countries of origin, looking for better situations rarely returning back. To include Diaspora in process of development, two issues are important: one open migration chains to move to progressively complex educational and job tasks 
in global environment, and two Diaspora networks are locus of concerted action by expatriates to promote their collective interests or to help them engage in their home countries (Kuznetsov, Nemirovsky and Yoguel, 2003). Thus, it is vital to understand 'what would we expect from Diaspora'? In past, expatriates have played a critical role in accelerating technology exchange and foreign direct investment in economies of India, China and Israel by taking role of pioneer investors at a time when major capital markets regarded these economies as too risky. There have been qualitative differences in network types used by different occupational classes (Wong, Ho, and Singh, 2007). For example, high occupational groups rely more on networks of colleagues or organizations and less on kin-based networks than unskilled workers. Types and characteristics of these networks may depend on their composition - friends, relatives, kin, acquaintances, professional colleagues, etc. However, most positions are acquired via connections. Thus, Diaspora plays a strategic and systematic role in technology transfer, foreign direct investment and identification and penetration into reliable knowledge and business networks.

How do we attract Diaspora, or otherwise, how do we play brain gain game? Since 1990s, highly skilled labour mobility with tertiary degree or extensive specialized work experience has been a burgeoning. Thus, there is need to focus on talents in fields of architects, accountants, financial experts, engineers, technicians, researchers, scientists, chefs, teachers, health professionals and increasingly specialists in IT including computing professionals, computing engineers, managers, sales professionals, etc. In present century, knowledge is recognized to be most important factor in economic development (Kuznetsov and Sabel, 2006). Richer countries compete to attract and retain world's best trained minds in many ways. More influential "pull" factors of professional migration are envisaging effective policies that stimulate R\&D activities and increase direct investment, offering attractive post-graduate training and research opportunities, and recruiting younger graduates and professionals. University is obviously a critical factor in "brain gain" game. Their linkages to industries, local or global, would determine intellectual drive and momentum for innovation.

\section{CONCLUSION}

Different countries have different talent endowments linked to their demography, educational system, and ability/will to attract, retain, or export talented workers. Many European countries will face serious "talent crunches" in near future particularly in areas of e-skills, scientific and engineering professions. Large emerging Asian countries including India and China will also be increasingly faced with a talent shortage at home due to their fast economic growth. Thus, these countries will need to develop appropriate national talent pools. There is need for further exploration and quantification of global talents to anticipate main flows and forces in increasingly fluid world of mobile talents. Physical mobility of highly skilled may mean brain drain. The closely linked phenomenon is temporary labour movements, which facilitates acquisition of foreign knowledge and culture and establishment of business and 
personal networks across borders, all of which are potentially beneficial for country of origin. IT and emergence of global networks are radically changing the mobility equation by introducing new ways to combine talents across national borders. Recently, outsourcing (especially business process outsourcing) has been one of main beneficiaries of this phenomenon, as well as all sectors in which virtual teams can be organized for production, maintenance, marketing, sales, or distribution of complex products and services. Virtual mobility has become a key element in development of exports of IT services in India. Large multinational groups have been among fastest growing users.

Numbers of potential migrants who invest in human capital are greater than the number of actual migrants. This results in an additional accumulation of human capital, which could stimulate higher demand for quality tertiary education that needs to be competitively matched. Potential benefits of brain circulation through Diaspora networks are closely linked to level of investment in higher, technical and scientific education coupled with political and economic stability, which encourages highly skilled immigrants to return home and invest his/her skills, time and money in the process. Therefore, there is urgent need to reform tertiary education to make it responsive to the labour market needs both in India and outside to maximise the benefits of brain-gain. Effectiveness of investment in higher, technical and scientific education rests heavily on its contribution to improved quality of the tertiary education system, political stability, sound economic policies leading to viable private sector development, and existence of robust regulatory institutions.

Besides, there is need to establish standards of good governance including protection of property rights and enforcement of rule of law through a reputable and independent judiciary system. It also calls for need to create a competitive, merit-based and properly compensated civil service system. High financial cost is associated with return option, which needs to be compensated with required incentive packages. There is also need to pay adequate attention to the tensions that can be created by offering better privileges to returnees which are not enjoyed by those in same vocations back at home. Both sending and host countries can benefit from brain gain through emerging trend towards trans-nationalization due to globalization, which makes it possible to live in two countries simultaneously. Current trend towards a 'knowledge society' gives more importance on human beings who carry the knowledge. Therefore, there is need to pay required attention to design and promote innovative policy environments that could be instrumental to benefit from 'brain gain' potential in Asian developing countries. Thus, new policy initiatives should include monetary and non-monetary incentive packages, tax and bureaucratic reforms, targeted infrastructure development, political and administrative support to knowledge and business networks, linking education programmes with labour market needs, fostering partnership between universities and industries etc. to make the process of 'brain gain' through Diaspora network beneficial to both development of home country as well as to international human capital stock and knowledge flows. In brief, the paper emphasizes beginning of a new 
agenda of promoting policy reform and institutional innovation in collaboration with Diasporas networks, which can be crucial bridges between policy, technological and managerial expertise and local scenarios. Public policy reform, educational innovations and promotion of a knowledge-based private sector are few areas where Diasporas members could team up with local governments and external funding agencies to tap Indian talents and promote equitable development.

\section{References}

Adams, R. (2003). International migration, remittances and the brain drain: A study of 24 labourexporting countries. World Bank policy research working paper 3069. Washington, DC: World Bank.

AAPI (2009). American Association of Physicians of Indian Origin. http://aapiusa.org/members/ why-join-aapi.aspx.

Agrawal, A., Kapur, D. \& McHale, J. (2008). Brain drain or brain bank: The impact of skilled emigration on poor-country innovation. NBER working paper no. 14592.

Beine, M., Docquier, F. \& Rapoport, H. (2001). Brain drain and economic growth: Theory and evidence. Journal of Development Economics, 64(1), 275-89.

Beine, M., Docquier, F. \& Rapoport, H. (2008). Brain drain and human capital formation in developing countries: Winners and losers. Economic Journal, 118, 631-652.

Brown, G. (2005). Putting Britain at the forefront of global trade, The Financial Times. 4 Carrington, W. J. \& E.

Detragiache (1998). How big is the brain drain? IMF working paper WP/98/102. Washington, DC: International Monetary Fund.

Chen, D. \& Dahlman, C. J. (2004). Knowledge and development: A cross-section approach, World Bank, 4-88.

Docquier, F., Lowell, B. L. \& Marfouk, A. (2009). A gendered assessment of the brain drain, Population and Development Review, 35, 297-321.

Dumont, J.C. \& Lemaitre, G. (2007). Counting immigrants and expatriates: A new perspective. Social employment and migration working papers. OECD, retrieved from http://www.oecd. org/dataoecd/27/5/33868740.pdf

The economist (2006). Opening the doors. October 5.

European Commission (2002). Presidency conclusions: Barcelona European Council. 15 \& 16 March 2002, SN 100/02, Brussels.

European Commission (2003). Investing in research: An action plan for Europe. COM (2003)226 final and Europe must take action to compete in global market for researchers. CORDIS News, www.cordis.lu.era/mobility.htm. 25 November 2003.

Fukasaku, K. (2004). Overview: Miracle, crisis and beyond, Paris: OECD Development Centre, 1920 April. 
Garson, J. P. (2001). Main trends in international migration. A paper prepared for the workshop on international migration and labour market in Asia. Organized by the Japan Institute of Labour, OECD and ILO. 1-2 January 2001. Tokyo: Japan Institute of Labour.

Guellec, D. (2002). Human resources: A potential 3\% bottleneck. Presentation to the European Commission, DG Research, 5 November.

Heidrick \& Struggles/Economist Intelligence Unit (2007). Global talent index 2007-2012, Available at http://www.weknowglobaltalent. com/gti/window/gti.

Hunger, U. (2002). The "brain gain" hypothesis: Third-world elites in industrialized countries and socioeconomic development in their home country. San Diego: The Center for Comparative Immigration Studies, University of California. Working paper 47, Available online at http://www.ccis-ucsd.org/PUBLICATIONS/wrkg47.PDF.

Iguchi, Y. (2002). Movement of the highly-skilled in Asia: Present situation and future prospect. Migration and the Labour Market in Asia: Recent Trends and Policies. Tokyo: Japan Institute of Labour.

India Labour Report (2009). The geographic mismatch and a ranking of Indian states by their labour ecosystem, New Delhi: TeamLease and IIJT.

Institute for Statistics (2009). EdStats, UNESCO, August.

Ivaturi, V.K., Bruno L. \& Hrishi, M. (2009). Global mobility of talents: What will make people move, stay, or leave in 2015 and beyond? The global information technology report 20082009. World Economic Forum.

Johnson, J. (2001). Human resource contributions to US science and engineering from China. SRS Issue Brief. January.

Khadria, B. (2004a). Human resources in science and technology in India and the international mobility of highly skilled Indians. STI Working Paper 2004/7. www.oecd.org/sti/ working-papers.

Khadria, B. (2004b). Migration of highly skilled Indians: Case studies of IT and health professionals. STI Working Paper 2004/6. www.oecd.org/sti/working-papers.

Kerr, W. R. (2008). Ethnic scientific communities and international technology diffusion. Review of Economics and Statistics, 90, 518-537.

Kugler, M. \& Rapoport, H. (2007). International labour and capital flows: Complements or substitutes? Economics Letters, 94(2), 155-162.

Kuznetsov. Y. \& Sabel, C. F. (2006). Work globally, develop locally: Diaspora networks as entry point to knowledge-based development. Innovation: Management, Policy \& Practice. 8, 45-61.

Kuznetsov, Y., Nemirovsky, A. \& Yoguel, G. (2003). Argentina's renaissance as a knowledge economy: Role of the diaspora of highly skilled. World Bank Institute, 2-38.

Lanvin, B., \& Passman, P. (2008). Building e-skills for the information age. Global information technology report 2007-2008. Fostering innovation through networked readiness. Hampshire: Palgrave Macmillan, 77-90.

Lucus, R. E.B. (2001). Diaspora and development: Highly skilled migrants from East Asia. A report prepared for the World Bank, November. 
Mahroum, S. (2002). Europe and the prospect of brain drain. The IPTS Report, 66.Available at www. jrc.es/pages/iptsreport/vol66/english/STR1E666.html.

Marsh, P. (2004). World's manufacturers March into China. The Financial Times, 21 June, 11.

MCIT (Ministry of Communications \& Information Technology) (2009). Information technology annual report 2008-09. New Delhi: Government of India.

METI (Ministry of Economy, Trade and Industry) (2003). Japanese white paper on international trade. Section 2: Utilization of excellent overseas human resources. Tokyo.

Monger, R. \& Macreadie, B. (2009). Non-immigrant admissions to the United States: 2008, Annual flow report. Office of immigration statistics, Homeland security. April.

Mountford, A. (1997). Can a brain drain be good for growth in the source economy? Journal of Development Economics, 53, 287-303.

NCURA (2006). Guiding principles for university-industry endeavors. USA: National council of university research administrators (NCURA).

Ndulu, B. J. (2004). Human capital flight: Stratification, globalization, and the challenges to tertiary education in Africa, JHEA/RESA, 2(1), 57-91.

OECD (2001). International mobility of the highly skilled. Paris: OECD.

OECD (2003). Science, technology and industry scoreboard. Paris: OECD. www.oecd.org/sti/ scoreboard

OECD (2004a). Science, technology and industry outlook, Paris: OECD.

OECD (2004b). Main science and technology indicators, Paris: OECD.

OECD (2007). International migration outlook: SOPEMI - 2007 Edition. Paris: OECD.

Rai, S. (2004). From India, genius on the cheap. International Herald Tribune. 15 December, 12.

Saint-Paul, G. (2004). The brain drain: Some evidence from European expatriates in the United States. IZA discussion paper no. 1310, IZA, Bonn. ftp://ftp.iza.org/dps/dp1310.pdf.

Schaaper, M. (2004). An emerging knowledge-based economy in China: Indicators from OECD databases, STI working paper 2004/4. www.oecd.org/sti/working-papers.

Sheehan, J. \& Wyckoff, A. (2003). Targeting R\&D: Economic and policy implications of increasing R\&D spending. STI Working Paper 2003/8. www.oecd.org/sti/working-papers.

Song, W. \& Z. Xuan (2004). Preliminary analysis of China's doctor education. OECD Careers of Doctorates Workshop. September.

Tritah, A. (2008). The brain drain between knowledge based economies: The European human capital outflows to the US. CEPII working paper no. 2008-08.

UNDP (2003). Ownership, leadership and transformation: Can we do better for capacity development? Virginia: Earthscan Publication Limited.

UNDP (2008). Human development report 2007/2008. Table 1. Available at http://hdr.undp.org/en/ reports/global/hdr2007-2008/. 
UNDP (2007). Human development report 2007/2008. Palgrave Macmillan: Houndsmills, Basingstoke, Hampshire. Available at http://hdr.undp.org/en/reports/global/hdr20072008/.

UNESCO (2007). Education for all global monitoring report 2008. Education for all by 2015: Will we make it? Paris: UNESCO.

UNESCO (2009). Institute for statistics. Available at http://www.uis.unesco.org/ev.php?URL_ ID=2867\&URL_DO=DO_TOPIC\&URL_SECTION=201.

US Census Bureau (2009). International database. available at http://www.census.gov/ipc/www/ $\mathrm{idb} /$ pyramids.html

Vidal, J.P. (1998). The effect of emigration on human capital formation. Journal of Population Economics, 11, 589-600.

Von, W. J. (2006). A European blue card proposal. Horizons Strategiques, No. 1, July.

Von, W. J. (2008). Strait is the gate: Europe's immigration priorities. Bruegel policy brief 2008/05. July.

Wong, P.-K., Ho, Y.-P., \& Singh, A. (2007). Towards an "entrepreneurial university" model to support knowledge-based economic development: The case of the National University of Singapore. World Development, 35, 941-958.

World Bank Group (2008). Doing business 2009. Washington, DC: World Bank. Available at http:// www.doingbusiness.org/.

World Bank (2008). World development indicators online database. Washington, DC: World Bank.

World Economic Forum (2008). The global information and technology report 2008-2009. World economic forum. Executive opinion survey 2007. 